\title{
Frequency of haemoglobinopathies at premarital health screening in Dohuk, Iraq: implications for a regional prevention programme
}

N.A. Al-Allawi ${ }^{1}$ and A.A. Al-Dousky ${ }^{1}$

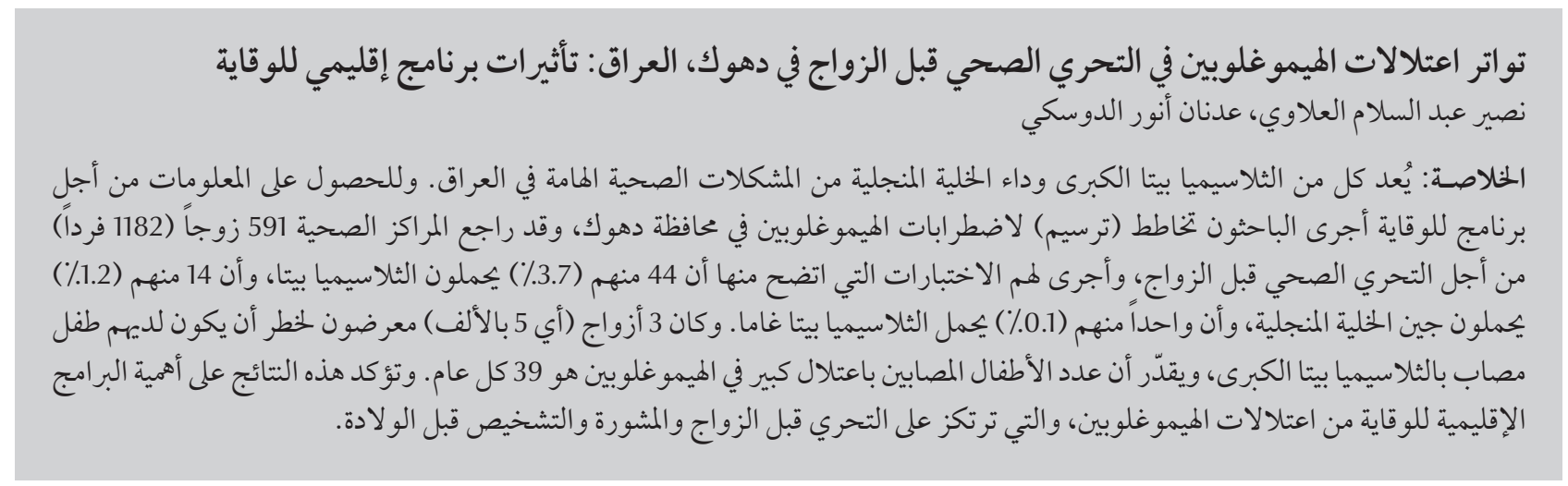

ABSTRACT $\beta$-thalassaemia major and sickle-cell disease are important health problems in Iraq. To provide information for a prevention programme, the frequency of haemoglobin disorders was mapped in Dohuk governorate. A total of 591 couples (1182 individuals) attending health centres for premarital health screening were tested; $44(3.7 \%)$ were found to be carriers of $\beta$-thalassaemia, $14(1.2 \%)$ of the sickle-cell gene and $1(0.1 \%)$ of $\delta \beta$-thalassaemia. A total of 3 couples (i.e. 5/1000) were at risk of having a child with $\beta$-thalassaemia major, and the estimated number of affected children with a major haemoglobinopathy was 39 per year. The findings stress the importance of a regional prevention programme for haemoglobinopathies based on premarital screening, counselling and prenatal diagnosis.

\section{Fréquence des hémoglobinopathies lors du dépistage prénuptial à Dohuk (Iraq) : implications pour un programme régional de prévention}

RÉSUMÉ La bêta-thalassémie majeure et la drépanocytose sont des problèmes sanitaires importants en Iraq. Une cartographie de la fréquence des hémoglobinopathies a été réalisée dans le gouvernorat de Dohuk, afin d'obtenir des informations pour un programme de prévention. Au total, 591 couples (soit 1182 individus) réalisant un dépistage prénuptial dans un centre de santé ont été testés. Parmi eux, 44 individus (soit 3,7 \% du total) étaient porteurs du gène de la bêta-thalassémie, $14(1,2 \%)$ du gène de la drépanocytose, et un seul $(0,1 \%)$ du gène de la delta-bêta thalassémie. Dans l'ensemble, trois couples (soit 5 pour 1000) risquaient d'avoir un enfant atteint de bêta-thalassémie majeure ; et le nombre annuel d'enfants atteints d'une hémoglobinopathie majeure a été estimé à 39. Ces découvertes soulignent l'importance d'un programme régional de prévention des hémoglobinopathies fondé sur le dépistage prénuptial, le conseil et le diagnostic prénatal. 


\section{Introduction}

Haemoglobinopathies are inherited disorders of globin chain synthesis that may either be quantitative (thalasssaemias) or qualitative (sickle-cell, $\mathrm{Hb}-\mathrm{C}$ or $\mathrm{Hb}-\mathrm{D}$ disease and others). They are the most frequent single gene disorders worldwide, particularly in the Eastern Mediterranean Region, including Iraq [1]. Following the earliest reports of thalassaemia major and sickle-cell disease from Iraq in the 1960s [2,3], these inherited disorders became increasingly recognized as important health problems, with centres established for their management throughout the country. The Dohuk governorate, which lies in the extreme north of Iraq, has more than 450 people with major haemoglobinopathies registered at its recently established centre. The continuous need for blood transfusion and cumbersome iron chelation therapy, which are the mainstays of management, impose a huge burden on already scarce health resources. This, together with the suffering of the patients and their families, has made initiating a preventive programme for these diseases a necessity rather than an option.

The proposed preventive programme would include premarital screening, counselling and prenatal diagnosis, which is based on the successful models established by Cyprus and the Islamic Republic of Iran $[4,5]$. Accordingly, this pilot study was initiated to test the feasibility of a premarital haemoglobinopathy screening programme by investigating the gene frequency of haemoglobinopathies in the region and estimating the number of couples who would benefit from such a programme.

\section{Methods}

This study was conducted from 15 January to 15 July 2006. The participants were couples attending primary health centres in Dohuk governorate, Iraq, for routine premarital investigations.

There are 6 such health centres in the governorate, 1 in each of its districts, that provide government-mandated premarital investigations, which currently include blood group analysis, testing for human immunodeficiency virus (HIV), hepatitis B virus (HBV) and syphilis, but not haemoglobinopathy screening. An average of 10-15 couples or 20-30 individuals are seen at these centres daily. All couples attending the health centres for premarital health screening in the first 3 working hours of alternate days of the week were sampled for this study. A representative proportional number of subjects from each district of the governorate was calculated based on a recent census (2005), and the numbers of those actually enrolled were recorded (Table 1).

This study was approved by the research council of the College of Medicine at the University of Dohuk and informed consent was obtained from all included participants.

A questionnaire was used for each individual to record age, sex, residence, familial relationship of the couple and family history of blood diseases. Out of a total of 1264 individuals (632 couples), 82 people were excluded because their blood samples were clotted, haemolysed or lost. Thus 1182 individuals (591 couples) were included, all of whom were permanent residents of Dohuk.

A $7 \mathrm{~mL}$ blood sample was taken from each person by venepuncture, and $3 \mathrm{~mL}$ was placed in an EDTA-anticoagulant tube for estimation of haematological parameters and red-cell indices, while the remaining $4 \mathrm{~mL}$ was collected in a plain tube for serum iron studies.

The red cell indices were determined within 24 hours of collection by electronic haematology analyser (Beckman-Coulter, United States of America) (calibrated daily by quality assurance reagents provided by the manufacturer). At the same time, a sickling test and haemoglobin electrophoresis on cellulose acetate (at $\mathrm{pH}$ 8.6) were performed on all 1182 samples using standard laboratory procedures [6].

Further testing was performed if mean corpuscular volume (MCV) was $<80 \mathrm{fL}$ and/or mean corpuscular haemoglobin $(\mathrm{MCH})<27$ pg. The HbA2 level was estimated by elution from cellulose acetate and $\mathrm{HbF}$ by alkaline denaturation [6]. Serum iron and total iron binding capacity were performed using a standard kit (BioLab, France).

$\beta$-thalassaemia minor was diagnosed by an elevated $\mathrm{HbA} 2>3.5 \%$, and sickle-cell trait by a positive sickling test confirmed by $\mathrm{HbS}$ band on electrophoresis [6]. Iron deficiency was diagnosed by a reduced transferrin saturation $<15 \%[7]$.

The anticipated number of affected births was calculated based on the carrier allele frequency and the Hardy-Weinberg equation, as detailed elsewhere [8].

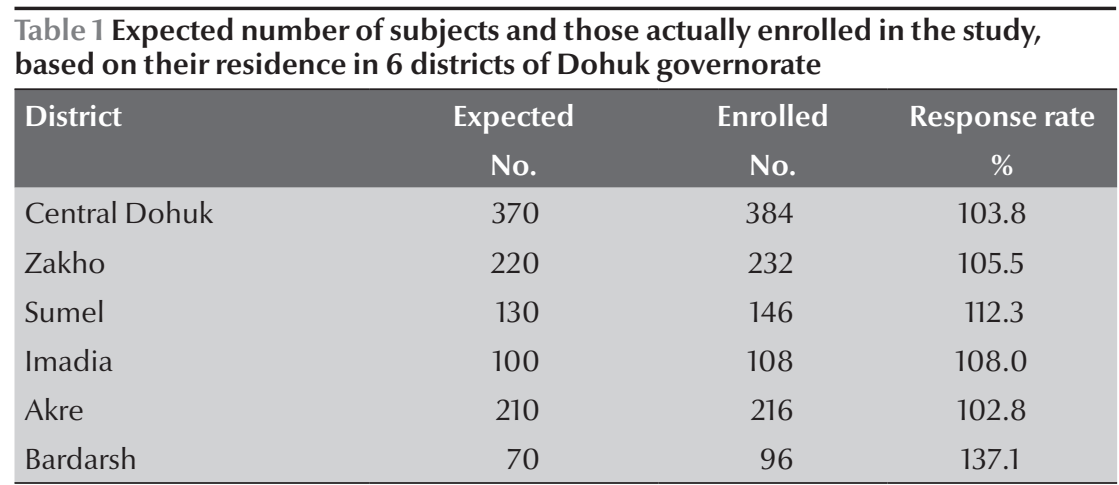




\section{Results}

The group tested for haemoglobinopathy carrier state consisted of 1182 individuals (591 couples) with an age range of 16-58 years for males (median 24 years) and 14-47 years for females (median 21 years). The consanguinity rate of these couples was $27.2 \%$ (second cousins or more closely related).

Of the 1182 individuals, 14 had a positive sickling test, which was identified by $\mathrm{Hb}$ electrophoresis as sickle-cell trait in 13 cases and sickle/ $\beta+$ thalassaemia in 1 case. Thus the overall prevalence of sickle-cell carrier state in the study group was $1.2 \%$.

Testing for $\beta$-thalassaemia minor among the 1182 individuals showed that 231 (19.5\%) had an MCV < $80 \mathrm{fL}$ and/or MCH $<27$ pg. Further studies on these 231 individuals confirmed a diagnosis of $\beta$-thalassaemia trait in 44 cases $(3.7 \%)$, iron deficiency in 66 cases (5.6\%), and $\delta \beta$ thalassaemia trait in 1 case $(0.1 \%)$ (Table 2$)$. There were regional differences in the distribution of the haemoglobinopathy carrier states in the districts of the governorate, with the highest frequencies of $\beta$-thalassaemia in Bardarash and sickle-cell carrier in Sumel (Table 2).

Inatotalof 23 couples (i.e.39/1000), both partners had hypochromic and/or microcytic indices or were sickle-cell carriers. However, $\beta$-thalassaemia carrier state was confirmed in both partners in only 3 of these couples $(5 / 1000)$. Thus 3 out of the 591 tested couples were at risk of having thalassaemia major/intermedia children. There were no couples who were at risk of having sickle-cell diseased children.

The records of the Dohuk Directorate of Health showed that 6545 couples had premarital screening in 2005. Based upon this number, it is estimated that 255 couples or 510 individuals a year would require further testing because they both had reduced $\mathrm{MCV} / \mathrm{MCH}$ or positive sickling tests. It is further estimated that for 32-33 couples both partners would be carriers and at risk of having affected children.

Using the Hardy-Weinberg equation, the overall predicted proportion of children born with a major haemoglobinopathy (sickle-cell disease, $\beta$-thalassaemia major/intermedia) would be $0.63 / 1000$. There were 36612 live births in the year 2005 in the Dohuk region recorded by the Directorate of Health. Accordingly, it is projected that around 23 children would be born annually with a major haemoglobinopathy. This number would apply if all marriages were unrelated, but correction for consanguinity of $27.2 \%$ would increase the predicted annual number of children born with major haemoglobinopathies to around $39(1.07 / 1000)$.

\begin{tabular}{|c|c|c|c|c|c|c|}
\hline \multicolumn{7}{|c|}{$\begin{array}{l}\text { Table } 2 \text { Prevalence of } \beta \text {-thalassaemia and sickle-cell carrier states and of iron } \\
\text { deficiency among individuals attending premarital health screening in } 6 \text { districts } \\
\text { of Dohuk governorate }\end{array}$} \\
\hline \multirow[t]{2}{*}{ District } & \multicolumn{2}{|c|}{$\begin{array}{c}\beta \text {-thalassaemia } \\
\text { carrier }\end{array}$} & \multicolumn{2}{|c|}{$\begin{array}{c}\text { Sickle-cell } \\
\text { carrier }\end{array}$} & \multicolumn{2}{|c|}{ Iron deficiency } \\
\hline & No. & $\%$ & No. & $\%$ & No. & $\%$ \\
\hline Central Dohuk $(n=384)$ & 11 & 2.9 & 7 & 1.8 & 26 & 6.8 \\
\hline Zakho $(n=232)$ & 7 & 3.0 & 1 & 0.4 & 8 & 3.5 \\
\hline Sumel $(n=146)$ & 5 & 3.4 & 4 & 2.7 & 7 & 4.8 \\
\hline Imadia $(n=108)$ & 4 & 3.7 & 1 & 0.9 & 6 & 5.6 \\
\hline Akre $(n=216)$ & 6 & 2.8 & 1 & 0.5 & 16 & 7.4 \\
\hline Bardarash $(n=96)$ & 11 & 11.5 & 0 & 0.0 & 3 & 3.1 \\
\hline Total $(n=1182)$ & 44 & 3.7 & 14 & 1.2 & 66 & 5.6 \\
\hline
\end{tabular}

\section{Discussion}

Dohuk governorate lies in the extreme north of Iraq, in the triangle between the Syrian Arab Republic, Turkey and the Islamic Republic of Iran. Its population of 900000 is scattered among 4 main cities and tens of small towns and villages, entrenched in a mountainous terrain. The prevalence rate of $3.7 \%$ for $\beta$-thalassaemia trait in this governorate is slightly lower than the $4.4 \%$ reported from Baghdad, Iraq's capital, in the centre of the country [9], and the $4.6 \%$ reported from Basra in the extreme south [10]. The prevalence rates for $\beta$-thalassaemia vary in surrounding countries, with an overall figure of $2 \%$ in Turkey [11] and 4\%-10\% in various regions of the Islamic Republic of Iran [12]. A figure of $3.0 \%-3.4 \%$ was reported from Saudi Arabia [13,14], while prevalence in Jordan was reported to be 3.0\%-3.5\% [15-17]. In the Syrian Arab Republic, the estimated prevalence was $5 \%$ [8].

On the other hand, the prevalence of sickle-cell carrier state (1.2\%) was much lower than the $6.5 \%$ reported recently from Basra [10]. To our knowledge, no other formal studies have been performed in other regions of Iraq. Studies from surrounding countries reported a prevalence in Jordan that varied between $1 \%$ and $4.5 \%$ depending on the region $[17,18]$. Saudi Arabia has wide differences, with rates that vary regionally but with a national average of $5.7 \%[14,19]$. In Turkey, the prevalence of sickle-cell genes is $4.9 \%$ overall, and in eastern Anatolia (the region bordering Dohuk) it is $1.7 \%$ [20]. Studies from the south of the Islamic Republic of Iran report a sickle-cell gene frequency of $1.5 \%[21]$.

The proportion of couples in whom both partners had hypochromic and/ or microcytic red-cell indices or were sickle-cell carriers was only $3.9 \%$ of the total number coming to premarital clinics. This is an important service indicator, 
because it was a relatively small proportion of couples that required further testing. The goal of a premarital screening programme is to reduce the number of affected children, and there is no need for further testing if only 1 partner has a positive sickling test or reduced red-cell indices while the other is normal.

The 5/1000 couples at risk of conceiving affected children in Dohuk is abouthalf that estimated in Basra [10].It is much nearer to a figure reported from the Islamic Republic of Iran at 4.5/1000 [5], but is higher than that reported from Turkey, where 1.5/1000 couples were at risk of having an affected thalassaemic child [22]. The differences noted above are relevant to the prevalence rates of thalassaemia and sickle-cell genes in these particular populations.

Another indicator for service needs is the estimate of 39 neonates affected annually with major haemoglobinopathies. This estimate compares well with the 42 new cases identified for the year 2005 by the registry of the Dohuk thalassaemia centre. This figure emphasizes the potential recurring burden of disease that could accrue in this region and the need for an effective prevention programme to reduce that burden.

While the current study indicates that a premarital screening programme for haemoglobinopathies may be justified in our region, several limitations to the full success of such a programme should be noted. Among these limitations is that arranged and consanguineous marriages are quite common, and the fact that premarital screening is only performed days prior to the actual marriage, and not at the engagement stage. Both these factors make the option of separation for couples found to be at risk difficult and socially unacceptable, even after appropriate genetic counselling. Previous reports worldwide of the actual impact of genetic counselling on the couples at risk have been conflicting. So that, while some have suggested that its impact is minimal, others suggested that it may lead to separation in about half of these couples [23]. What is encouraging is that the latter figure came from the Islamic Republic of Iran, which neighbours Iraq and has a comparable cultural and social background [5]. This emphasizes the need for an ambitious educational programme, which involves all sectors of the community, including, particularly, religious leaders, who may play a pivotal role in public acceptance of the programme and its implementation. The programme should emphasize not only the suffering of affected children and their families and the value of premarital testing in preventing haemoglobinopathies, but should also attempt to discourage consanguineous marriages (especially in families with a history of genetic disease), and encourage earlier premarital testing, preferably before the couple becomes engaged to be married.

In conclusion, this study has demonstrated a relatively high prevalence of $\beta$-thalassaemia and to a lesser extent sickle-cell carrier states, together with high rates of consanguineous marriage in Dohuk. Furthermore, it provided some important indicators about the burden of disease, including the relatively small proportion of couples requiring further testing (3.9\%), and the limited numbers of those requiring genetic counselling $(0.5 \%)$. These indicators would give the health authorities guidelines for the number of staff required and costs of a preventive programme.

These findings, together with the results of our previously published results on the molecular characterization of $\beta$-thalassaemia mutations in the region, which revealed that 8 main mutations constitute $81.7 \%$ of all mutations characterized [24], will help set the stage for initiating a regional preventive programme for haemoglobinopathies, based on the concept of premarital screening, genetic counselling and prenatal diagnosis. This approach is considered the best option for the control and management of inherited haemoglobinopathies [25]. The success of this approach has been demonstrated in Europe, where the affected birth rates fell almost 100\% between the late 1970s and late 1980s in Cyprus and Sardinia, and about $80 \%$ in Greece and Italy [26]. In less-developed countries such as the Islamic Republic of Iran, it is believed that births of babies with severe thalassaemia fell to about $30 \%$ of expectation [5]. Several investigators have shown that this approach is cost-effective, and studies from Cyprus demonstrated that the cost of an 8-week preventive programme was equivalent to 1 week of treatment for the thalassaemic population [4]. The value of prenatal diagnosis as an integral and cost-effective part of such a preventive approach was addressed by Modell and Kuliev, who calculated that the cost incurred by terminating an affected pregnancy and subsequently having a normal child was only $30 \%$ of the annual treatment cost and $2 \%$ of the discounted lifetime cost of an affected child [26].

The findings of the current study and all the above facts discussed support the notion of establishing a preventive programme for haemoglobinopathies based on the concept of premarital screening, counselling and prenatal diagnosis with the aim of reducing the numbers of affected children born in the region.

\section{Acknowledgements}

This study was sponsored by the Ministry of Health of the Kurdistan regional government, Iraq. The authors are grateful to Professor Michael Hughson (University of Mississippi Medical Centre, USA) for reviewing the manuscript and Professor Bernadette Modell (University College London, UK) for her assistance in calculating the number of estimated affected homozygotes (corrected for consanguinity). 


\section{References}

1. Weatherall DJ, Clegg JB. Thalassaemia syndromes, 4th ed. Oxford, Blackwell, 2001.

2. Taj El-Din S et al. Thalassaemia in Iraq. Annals of tropical medicine and parasitology, 1968, 62:147-53.

3. Baker F, Al-Quasi M. Sickle cell anemia in Iraq: first case report. Journal of the Faculty of Medicine, Baghdad, 1964, 6(5):26-31.

4. Angastiniotis MA, Kyriakidou SM, Hadjiminas M. How thalassemia was controlled in Cyprus, World health forum, 1986, 7:291-7.

5. Samavat A, Modell B. Iranian national thalassaemia screening programme. British medical journal, 2004, 329:1134-7.

6. Lewis SM, Bain BJ, Bates I, eds. Dacie and Lewis practical haematology, 10th ed. Philadelphia, Churchill Livingstone, 2006.

7. Hoffbrand VA, Catovsky D, Tuddenham GD, eds. Postgraduate haematology, 5th ed. Oxford, Blackwell, 2005.

8. Galanello R et al. Prevention of thalassemias and other haemoglobin disorders, vol. 1. Nicosia, Cyprus, Thalassaemia International Federation, 2003.

9. Yahya $\mathrm{HI}$ et al. Thalassaemia genes in Baghdad, Iraq. Eastern Mediterranean health journal, 1996, 2 (2):315-9.

10. Hassan MK et al. Frequency of haemoglobinopathies and glucose-6-phosphate dehydrogenase deficiency in Basra. Eastern Mediterranean health journal, 2003, 9(1/2):1-8.

11. Cavdar AO, Arcasoy A. The incidence of $\beta$-thalassaemia and abnormal hemoglobins in Turkey. Acta haematologica, 1971, 45(5):312-8.

12. Habibzadeh $\mathrm{F}$ et al. Thalassaemia in Iran: an overview. Archives of Iranian medicine, 1998, 1:27-33.

13. Al-Suliman A. Prevalence of $\beta$-thalassaemia trait in premarital screening in Al-Hassa, Saudi Arabia. Annals of Saudi medicine, 2006, 26(1):14-6

14. Ganeshaguru K et al. Prevalence of thalassaemia in ethnic Saudi Arabians. Tropical and geographical medicine, 1987, 39(3):238-43.
15. Babiker MM, Bashir N, Sarsour N. Prevalence of thalassaemia in school children in north-eastern Badia, Jordan. Eastern Mediterranean health journal, 1999, 5(6):1165-70.

16. Bashir N, Barkawi M, Sharif L. Prevalence of hemoglobinopathies in schoolchildren in Jordan valley. Annals of tropical paediatrics, 1991, 11:373-6.

17. Bashir $\mathrm{N}$ et al. Prevalence of hemoglobinpathies in North Jordan. Tropical and geographical medicine, 1992, 44:122-5.

18. Sunna El et al. Prevalence of hemoglobin $\mathrm{S}$ and beta-thalassaemia in northern Jordan. Journal of obstetrics and gynaecology research, 1996, 22(1):17-20.

19. El-Hazmi MA, Warsy AS. Appraisal of sickle-cell and thalassaemia genes in Saudi Arabia. Eastern Mediterranean health journal, 1999, 5(6):1147-53.

20. Tadmouri GO et al. Molecular and population genetic analyses of $\beta$-thalassaemia in Turkey. American journal of hematology, 1998, 57:215-20.

21. Habibzadeh $\mathrm{F}$ et al. The sickle cell gene frequency in southern Iran. Journal of tropical pediatrics, 2000, 46(3):181.

22. Keskin A. Premarital screening of beta-thalassaemia trait in the province of Denizli, Turkey. Acta haematologica, 2000, 104(1):31-3

23. Jamison et al., eds. Disease control priorities in developing countries, 2nd ed. Oxford, Oxford University Press, 2006.

24. Al-allawi NAS, Jubrael J, Hughson M. Molecular characterization of $\beta$-thallasaemia in the Dohuk region of Iraq. Hemoglobin, 2006, 30(4):479-86.

25. Alwan A, Modell B. Community control of genetic and congenital disorders. Alexandria, World Health Organization Regional Office for the Eastern Mediterranean, 1997 (WHO EMRO Technical Publications Series, No. 24).

26. Modell B, Kuliev AM . Service for thalassaemia as a model for cost-benefit analysis of genetics services. Journal of inherited metabolic disorders, 1991, 14(4):640-51. 